\title{
Preliminary Study on Application of Formative Assessment in College English Writing Class
}

\author{
Yang Liu \\ Changchun University of Science and Technology, China
}

\begin{abstract}
Educational assessment mainly consists of two manifestations: formative assessment and summative assessment. Formative assessment is ongoing assessment on learning process of students. It provides feedbacks for teacher and student through the course of teaching so as to help the teacher to improve methodology to satisfy the need of students and to promote the development of English teaching. Summative assessment is commonly considered as a major form of assessment, and it is an assessment focusing on result. Test achievement of student is its major criterion to evaluate the ability of student and the quality of teaching; therefore, it is a periodical assessment. The present paper reviews the origin of formative assessment, and discusses its application in college English writing class. The compositions of the experimental class students have more novel ideas and their teamwork and cooperation consciousness have been strengthened. The conclusion is that the application of formative assessment is beneficial in advancing students' writing ability and cultivating their team spirit. Some suggestions on effective application of formative assessment in writing class are put forward at last.
\end{abstract}

Index Terms — formative assessment, summative assessment, college English writing class, questionnaire

\section{INTRODUCTION}

Nowadays, assessment is playing an important role in college English instruction. In the process, assessment becomes an integral part of instruction and a guarantee of realizing instructional goals. Appropriate assessment methods are very essential because they can not only help students know about the focal points of courses and learning progress, enhance their confidence and improve their enthusiasm, activity and creativity in learning, but also assist teachers in understanding their teaching effects, reviewing and improving their teaching. Western education ideology has always been dominant in the world. It has laid a foundation for the development of the theory of education assessment. The most prominent achievement is the "Eight Year Study" initiated by American psychologist Tayler (1931) and other psychologists in the 1930s. The research makes education measurement shift to education assessment. The "Eight Year Study" contains topics such as the analysis and reflection of education objectives, objective system and feedback system. Tayler also definitely and explicitly distinguished between education assessment and education measurement. Since the 1960s, Bloom, an educational psychologist, and Scriven, an educationist, have pioneered a new era of education assessment. They set education objective as the research object of education assessment. The publication of Scriven's Methodology of Assessment (1967) indicated the turn of American education assessment. In the 1970s, people began to focus on the process of assessment and to emphasize the individual difference in assessment. Bloom's Taxonomy of Education Objective (1981) analyzed the identity of assessment objective and education objective from cognitive domain, affective domain and psychomotor domain. Handbook of Formative and Summative Assessment on the Study of Students (1971) and Education Assessment (1986), anther two books by Bloom, paid much attention to the promotion of assessment on the individual development. Students are to cultivate their skills, rather than to be confined to books, to study things in order to apply them and pay more attention to practice, to explore and to create. Accordingly, their ideology of assessment is to set the development of students as their main objective. In the 1970s, the traditional assessment notion was changed by the modern assessment criteria, which attached importance to collaborative assessment, self-assessment and other plural assessment methods.

In China, formative assessment measures have already been introduced into the English teaching of middle school, primary school, as well as for English majors, which is helpful to teaching and learning. However, as far as the college English teaching is concerned, formative assessment has not been able to be integrated into the current assessment system. It seems as if it has not been listed on the agenda. And little work on using formative assessment strategies has been done. Besides, little attention has been paid to effect of assessment on college learners.

On the other hand, summative assessment plays a leading role in educational field. Excessive attention has been paid to the scores of students. Students' marks in test are the only means of judging their learning level and ability. This kind of traditional assessment neglects the different interests, ability and learning methods of students. It is no good to help the students make good performance, enhance their confidence, build up their creativity in learning and to help teachers improve their teaching and understand their teaching effect. Thus, in order to make up the deficiency of summative assessment, it is necessary to apply formative assessment to instruction.

On this account, the paper is planned to analyze the relevant theories of formative assessment and discuss its practical 
significance in college English writing teaching. It contains five parts. Part one makes a brief introduction of formative assessment. Part two includes the definition of formative assessment and the comparison between formative assessment and summative assessment. Part three presents an experiment of formative assessment that is intended to cultivate the students' autonomous learning abilities, cooperative learning awareness and creative learning potentials, and to change the results of their behaviors by means of various assessment methods during the process of learning. Part four focuses on the results and the discussion of the experiment. The paper comes to a conclusion in part five, which discusses the findings and the issues that call for further research.

\section{THEORETICAL BACKGROUND}

\section{A. The Concept of Formative Assessment}

The term "formative assessment" was first introduced by Scriven (1967). After him many researchers have conducted substantial studies on different aspects of formative assessment both at home and abroad. Formative assessment is also called classroom evaluation, classroom-based evaluation, or classroom assessment. "Assessment for learning" is also used to distinguish it from "Assessment of learning". As Black and William (1998) say although different terms are used, they mean the similar thing.

Formative assessment evaluates the efficacy of the teaching activity itself during the process of teaching in order to adjust the process of activity and to ensure that the goals of the instruction are being achieved. It may be carried out in the way of class observation, weekly notes, interview, questionnaires, portfolios of student score, homework, tests and student assessment and so on. Formative assessment includes the self-assessment of students, the peer -assessment of students, teacher-assessment on students, and the collaborative assessment between students and teachers. The key point of formative assessment is the actual tasks and activities performed by students who are the subject of formative assessment. It is used to cultivate the practical skills and communicating skills of student in college foreign language teaching. Firm evidence shows that formative assessment is an essential component of class work and that its development can raise standards of achievement in classroom. (Black and William, 1998a (5):1-74., and 1998b, 80(2): 139-148; Luo, 2003, 23-26; Yu, 2004, 32-35).

Different definitions of it given by different scholars are listed as follows:

Formative assessment is the process used by teachers or students to recognize and respond to students learning in order to enhance that learning, during the learning. (Cowie and Bell, 1996)

Formative assessment is encompassing all those activities undertaken by teachers, and by their students, which provide information to be used as feedback to modify the teaching and learning activities in which they are engaged. (Black and William, 1998)

Gipps (1999) put forward another definition that Formative assessment has been defined as the process of appraising, judging or evaluating students' work or performance and using this to shape and improve students' competence.

All these definitions have one mutual understanding that formative assessment is a process, one in which information about learning is evoked and then used to modify the learning and teaching activities in which teachers and students are engaged. Formative assessment includes the involvement of both teachers and students; and that formative assessment includes the notion of feedback. The goals of formative assessment are to find potentials of every student, to stimulate students' learning, to provide qualitative feedback for teachers so as to help them modify their teaching methods and content. Therefore, the instructional efficiency can be raised.

\section{B. The Characteristics of Formative Assessment}

In educational assessment, formative assessment intends to enhance the quality of teaching activity by means of researching on the need of society, the need of educational participants, feasibility and problems existing in instructional process. The characteristics of formative assessment are summarized as follows:

(1) Formative assessment directly relates to the ongoing educational activity, focusing on improving this activity, therefore, it is the assessment in process, however, not the whole process of educational activity. In brief, formative assessment is analytical, emphasizing the feedbacks of teachers and students and complicatedly intervening in teaching process. Formative assessment can help to find out the problems in instruction so as to carry out new or remediable measures in time.

(2) Formative assessment relies on nonverbal as well as verbal information, for example, teachers can observe students, in terms of their facial expressions, body language, listening, talking and writing. The sources of formative assessment for teachers include the teacher's work in their books, notes, and homework; and teacher's listening to students' speech, questions. Teachers can set up different learning situations to provide the opportunities for this information to be elicited.

(3) The most important characteristic of formative assessment is the purpose for which it was done. The two main purposes of formative assessment are to inform the students' learning and to inform their teaching. (Bell and Cowie, 2001) The purposes to support the students' learning include monitoring the progress and learning or understanding the students during the teaching and learning. The purposes to support teaching include planning in the current lesson and unit; planning for future teaching; knowing when to input new ideas and when to move on to the next topic; knowing when to introduce an activity to maintain interest and motivation; evaluating the actions taken in previous formative 
assessment and teaching activities; finding out if the students have understood or not; providing information to report to students, caregivers and the school; and providing assessment information additional to the quantitative marks on achievement in reporting.

\section{Summative Assessment vs. Formative Assessment}

Summative assessment has dominated research and development because of status and the high stakes involved. It is the assessment focusing on the final results when certain teaching activity comes to an end. Scriven (1967) coined the term 'summative assessment' to describe outcomes assessment that yields an external, terminal judgment, as distinct from what he calls 'formative evaluation', which provides internal, continual feedback to the performer-in-action. Different from formative assessment, summative assessment, or formal assessment, takes place after instruction. Its primary purpose is to assess students' learning results. Final tests for a grading period, assessment at the end of a unit, and the end of the year are all typical sources of summative data. Teacher's primary role is to transmit course content, and learners are passive accumulators of information and knowledge. We are all quite familiar with this type of assessment in the form of term paper, term examination and research project. It is cost-efficient in terms of the time allocated to implementing assessment, and the test often assesses a range of content, including both major concepts and details. Besides advantages, its disadvantages, as mentioned above, are that it ignores students' foreign language learning process, misleads students' learning goals, reverses the relation of teaching and assessment, causes serious testing anxiety and provides little opportunity for teaching again. Occurring during learning process, formative assessment provides ongoing feedback to teachers and students. Its methods include classroom observation, portfolios, questionnaires and interviews. Formative assessment is integrated with teaching on a daily basis. It is flexible and idiosyncratic.

The following table illustrates the differences between formative assessment and summative assessment.

\begin{tabular}{|c|c|c|}
\hline & Formative assessment & Summative assessment \\
\hline Purpose & $\begin{array}{l}\text { To monitor and improve instruction and } \\
\text { student learning }\end{array}$ & To document student performance on a learning unit \\
\hline $\begin{array}{l}\text { Time of } \\
\text { assessment }\end{array}$ & During instruction & After instruction \\
\hline $\begin{array}{l}\text { Assessment } \\
\text { strategies }\end{array}$ & $\begin{array}{l}\text { Informal observation, listening to student's } \\
\text { questions and their responses to teacher's } \\
\text { questions, portfolios, journals }\end{array}$ & $\begin{array}{l}\text { Chapter test, final exams, reports, term papers, } \\
\text { projects }\end{array}$ \\
\hline Content & $\begin{array}{l}\text { Specially related to what has been taught, i.e. } \\
\text { content is in harmony with what has been } \\
\text { taught }\end{array}$ & $\begin{array}{l}\text { Not necessarily related immediately to what has been } \\
\text { taught }\end{array}$ \\
\hline $\begin{array}{l}\text { Use of } \\
\text { information }\end{array}$ & $\begin{array}{l}\text { To improve a process while it is still going on; } \\
\text { to be focused on the individual learner's } \\
\text { specific strengths and } \\
\text { weaknesses, needs, etc. }\end{array}$ & $\begin{array}{l}\text { To judge success of student's learning and instruction } \\
\text { and to identify systematically student's errors; To feed } \\
\text { the judgment about a learner's performance into } \\
\text { record-keeping and be used for administrative } \\
\text { purposes, e.g. to check standards and targets }\end{array}$ \\
\hline Structure & Flexible, informal & Fixed, formal, standardized for all students \\
\hline Assessment design & $\begin{array}{l}\text { Students and parents assist the design of } \\
\text { assessment }\end{array}$ & $\begin{array}{l}\text { Teachers and managers determine the content and } \\
\text { criteria of assessment. }\end{array}$ \\
\hline Hypothesis & $\begin{array}{l}\text { The more opportunities students have for } \\
\text { self-development, the better they will study. }\end{array}$ & $\begin{array}{l}\text { The higher marks student get in tests, the harder they } \\
\text { will study }\end{array}$ \\
\hline Testing result & $\begin{array}{l}\text { To judge whether students have learned } \\
\text { something important in the learning process }\end{array}$ & $\begin{array}{l}\text { To judge students according to the established criteria } \\
\text { in advance }\end{array}$ \\
\hline $\begin{array}{l}\text { Reliability and } \\
\text { validity }\end{array}$ & $\begin{array}{l}\text { Reliability may reach acceptable levels with } \\
\text { training; validity is high. }\end{array}$ & Reliability is high; validity is not so high. \\
\hline
\end{tabular}

Through comparison, we know formative assessment can make up for some deficiencies of summative assessment. It can help teachers understand students' foreign language learning process, adjust teaching to satisfy students' various needs and improve teaching quality. It benefits both teaching and learning. In a word, formative assessment and summative assessment are complementary to each other. Teachers should combine them in a planned way. Only in this way can both teachers and students achieve the best effects.

\section{APPLICATION OF Formative AsSESSMENT IN WrITING ClASS: AN EXPERIMENT}

A. Research Questions

In the study, I put forward the following two research questions:

(1) Can formative assessment facilitate the writing ability of college students?

(2) Can formative assessment be considered as an alternative to summative assessment?

B. Participants

1. The Teacher and the Students

The subjects of this experiment study consist of 100 sophomores majoring in sociology in a college. The teacher (Shu) had had a three-year experience of teaching English writing at the time of the research. I, the writer of the paper, the 
co-researcher, and the designer of the experiment, assisted her in finishing this case study. The experimental class has 50 students, and the control class has 50 students, too. They each have one English writing class on Monday every two weeks. The students of the two classes hardly had any difference at English writing level before the experiment. They used the same textbook. Formative assessment was applied in the experimental class and summative assessment was continually practiced in the control class.

\section{Co-researcher}

As the co-researcher, the author, female, I attended every class through the whole process. I designed researching methods and collected data with teacher Shu. I represented myself as both teacher and student, so I had devoted myself into the research of applying formative assessment in college English writing teaching. Influenced by the traditional teaching and evaluating system, the students had already been accustomed to the conventional acceptance learning style and the evaluation method of written examinations. In view of this, there would be some difficulties in the research. On the other hand, it showed and proved the urgency and significance to adopt a new evaluation method. I am contented with the effect that most of them behaved active in English writing classes and had confidence and ability to express their ideas about how to write an excellent composition.

\section{Tools}

\section{Observation}

Informal observation is an integral part of everyday teaching: I continuously observed our students' language use during formal instruction or while the students were individually at their desks; I observed how students responded to and used instructional materials and how they interacted during group work; I observed how effectively they themselves were presenting particular lessons, units and so on. In order to take less time and get a general sense of students' learning, I divided each class into five groups. I observed students in two classes respectively during classroom activities such as whole class discussion and small group work. Besides observation, I organized writing conference on each Saturday morning every two weeks, which gives me a good opportunity to observe them carefully a wide range of writing-related skills. In the observation process, I used checklist to record the change of students through the whole experiment. Checklist is like a multiple-choice question with two response alternatives: yes or no. The following table is a checklist designed by myself to evaluate students' English writing skills.

\begin{tabular}{|l|l|l|}
\hline & Yes & No \\
\hline 1. Write words correctly & & \\
\hline 2. Use punctuation correctly & & \\
\hline 3. Use grammar well & & \\
\hline 4. Use sentence pattern correctly & & \\
\hline 5. Use tense markers correctly & & \\
\hline 6. Use prepositions properly & & \\
\hline 7. Read fluently & & \\
\hline
\end{tabular}

During the whole semester, I did ten times of checklist experiment. I only select three of them (first, fifth, ninth) to assist the experiment. Below is the percentage of selecting "yes" of the two classes.

\begin{tabular}{|l|l|l|l|l|l|l|l|}
\hline & 1 & 2 & 3 & 4 & 5 & 6 & 7 \\
\hline Class one & & & & & & & \\
\hline Class two & & & & & & & \\
\hline
\end{tabular}

On the basis of my observation, I assessed what students had or had not learned; I inferred the writing strategies students might be using that were facilitating or impeding learning; I analyzed which instructional activities and materials the students enjoyed. Information derived from such observation is fundamental to the day-to-day functioning of the classroom because it provides a basis for understanding what is happening and for making decisions about what should follow.

\section{Questionnaire I and Pre-test}

In their first English writing class, students in the experimental class were given a questionnaire (appendix I), written in Chinese and easy to understand. The experimental class participates in the questionnaire before their course, which includes the information about the students' attitudes towards English writing (quetions1, 3, 4, 5 \& 6), their writing habits (questions $2 \& 7$ ) and their writing skills (questions 8-12). So I designed different teaching programs and instruction process based on the data collected from questionnaire I. All the figures have been calculated and the results will be presented in the following part.

The two classes took English writing test at the beginning of the academic year as one part of the pre-test. Both classes took the pre-test of writing a composition in about 40 minutes (see the pre-test in appendix III). The pre-test paper was written based on the writing task of CET-4, which was designed to be at the same difficulty level and the same genre-argumentative writing as the post-test. The mean score of the two classes are used to answer whether there is significant difference between the two classes in English writing achievement before the experiment.

The data elicited from the questionnaire I and pre-test were used to help me know the writing ability of both classes and learn about the strength and weaknesses of the experimental class. 


\section{Portfolio}

Portfolio, a typical tool of formative assessment, is a purposeful collection of students' work that demonstrates to students and others their efforts, process and achievement in given area (Fred Genesee and Johna A. Upshur, 2001: 210-254). Portfolios are purposeful and require advanced planning. We aimed to document student's work and process so as to monitor and improve every individual's writing ability. Besides, students' self-assessments are very helpful for the teacher to learn about and document students' process. Because students were not familiar with the concept of portfolio, so we introduced its definition and purposes to them. At the same time, we designed some tables of must-included items in a portfolio and some checklist for self-assessment and peer-assessment. Finally, we assigned them three major writings, which would be evaluated and handed in. The cover page of the writing portfolio was designed as follows:

Writing portfolio
Student's name:
School year:
Grade:
Teacher's name:

We told students that their class performance, their after-class library researches would weigh 75 percent of the final grade at the beginning of the course (the rest 25 percent would be decided by the final exam score).

\subsection{Self-assessment}

Self-assessment plays an important role in English writing class and fully displays the principal-awareness of students. It is not only good to cultivate the earnest attitudes, but to stimulate to think correctly. In order to make a correct self-assessment, firstly we helped students make appropriate criteria of assessment, found out the factors of a good composition and provided an example. We let my student know what a good composition was like and make a proper assessment of their own composition. Factors of excellent composition include:

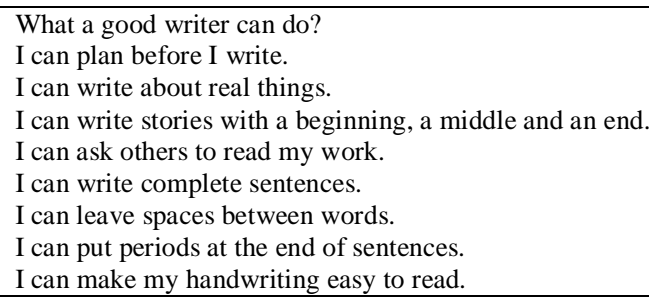

After carrying out a series of criteria, students began to assess themselves, make clear of their advantages and finish the self-assessment table (see below) carefully.

\begin{tabular}{|l|l|}
\hline Name & \multicolumn{1}{|l|}{ Date } \\
\hline Topic & Seriously choosing a novel topic \\
\hline Choosing: & Reasonable structure \\
Excellent, & Comprehensive content \\
Good, & Coherent and clear clues \\
Very good, & Consistent tense and person \\
Adequate, & Right punctuation and spelling \\
Need improvement & \\
\hline The place you need to improve: & \\
\hline
\end{tabular}

\subsection{Peer-assessment}

The significance of peer-assessment is to teach students the idea of being trusty, honest and fair to others. We divided four or five persons into a group with one monitor. After self-assessment and correction of first manuscript, groups should cooperate with and communicate with each other, discussing writings of group members. In this process, monitor should finish peer-assessment carefully. The peer-assessment table (see below) we designed is like this:

\begin{tabular}{|l|l|}
\hline Topic & Monitor \\
\hline Name & Group members \\
\hline Whether the main idea is clear & \\
\hline Whether the content is complete \\
\hline Whether the hierarchy is clear \\
\hline The advantage of composition \\
\hline Mistakes in composition \\
\hline Methods to improve the composition \\
\hline
\end{tabular}

Peer-assessment we made is with the help of the following questions: 


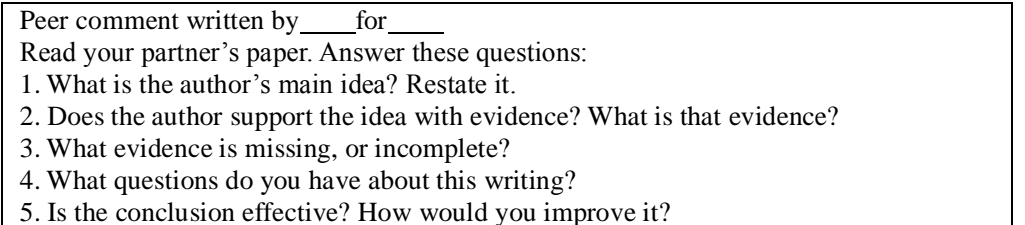

According to the feedback of students, some should improve their writings, and then a third correction. The final step was to hand in assessment to me. During the process, I designed the tables of self-assessment and peer-assessment, monitored my students, and organized their activities. We commented on their assessment-table and draft at the last step.

\subsection{Teacher-assessment}

We took part in every activity of the two classes, so our subjective estimate of the learners' overall performance or achievement can be quite accurate and fair. We got information by observing students in class, by questioning, by testing and by looking at their work.

Here is an observing record we applied in teacher-assessment:

\begin{tabular}{|lccc|}
\hline Student's performance in class: & & & \\
Student name: & Date:_ Rank: E: excellent G: good N: need improvement \\
Attendance of class: & E & G & N \\
Dictation: & E & G & N \\
Oral presentation: & E & G & N \\
Answering questions: & E & G & N \\
\hline Description on performance: & & & \\
\hline
\end{tabular}

\section{Questionnaire II and Post-test}

Questionnaire II (see appendix II) was completed by the experimental class after the course, which includes the information about students' attitudes towards English writing, their writing skills and their reflection about the writing course. Questionnaire II is the same as questionnaire I except for the last additional subjective question. I used the two data collected from the two questionnaires to compare students' attitudes towards English writing and their writing skills before and after the experiment. The two classes took the post-test (final exam) at the same time.

\section{Data Collection}

Data collection in this paper was conducted through the two questionnaires, the scores of the two tests and the observation. The experimental class students were given 10 minutes to finish questionnaire I before the course and 15 minutes to finish questionnaire II after the course. In case some students may not fully understand some of the statements, all the questions were written in Chinese.

Both the experimental and the control class students were given 40 minutes to finish pre-test (see appendix III) at the beginning of the course. They were given 60 minutes to finish the post-test (see appendix IV) at the end of the course.

Portfolios were handed to me at the end of the course, which included all the work students had done, including three major works, self-and-peer assessment.

\section{RESULTS AND DisCUSSION}

\section{A. Results}

\section{The Results of Questionnaires and Observation}

The comparison of the two questionnaires done by the experimental class is reflected in the following table.

\begin{tabular}{|l|l|l|l|l|l|l|l|l|l|l|l|l|}
\hline $\begin{array}{l}\text { Question number } \\
\text { Student number } \\
\text { Choice }\end{array}$ & 1 & 2 & 3 & 4 & 5 & 6 & 7 & 8 & 9 & 10 & 11 & 12 \\
\hline A2 & 12 & 12 & 12 & 16 & 20 & 10 & 12 & 4 & 2 & 2 & 4 & 2 \\
\hline A1 & 10 & 8 & 6 & 16 & 16 & 8 & 12 & 4 & 0 & 2 & 4 & 0 \\
\hline B2 & 14 & 16 & 16 & 10 & 12 & 16 & 18 & 20 & 26 & 26 & 24 & 30 \\
\hline B1 & 14 & 14 & 12 & 4 & 8 & 16 & 10 & 16 & 26 & 20 & 22 & 30 \\
\hline C2 & 18 & 18 & 16 & 14 & 12 & 18 & 14 & 14 & 16 & 16 & 18 & 10 \\
\hline C1 & 18 & 20 & 22 & 18 & 16 & 14 & 22 & 24 & 14 & 16 & 18 & 10 \\
\hline D2 & 6 & 4 & 6 & 10 & 6 & 6 & 6 & 12 & 6 & 6 & 4 & 8 \\
\hline D1 & 8 & 8 & 10 & 12 & 10 & 12 & 6 & 6 & 10 & 12 & 6 \\
\hline
\end{tabular}

We used the two questionnaires to determine whether students in the experimental class have made significant progress in their attitudes towards writing, their writing habits, and writing achievement by ways of formative assessment. Questions 1 and 3 are about students' attitudes towards English writing. There is no significant difference between both questionnaires. The reason may be that formative assessment is adopted in a short period and it is hard to 
change students' deep-rooted mentality towards English writing. While questions 4, 5 and 6 are about the assessment: teacher's comment, self-assessment, peer-assessment, respectively. The number of choosing answers C and D decreased, while that of choosing A and B increased. Therefore, we concluded that after the application of formative assessment in the experimental class, students get to understand the concept of portfolio and hold a positive attitude towards it. Question 2 is about how actively students accomplished their writing task. We found out that students accomplished their task more actively after the course according to the increased number of choosing A and B, and the decreased number of choosing C and D. According to question 7, students' revising frequency rose, which is really a positive phenomenon. Questions 8 to 12 are mainly about how excellent students performed in English writing from the aspect of opinion, organization, grammar, expression, sentence structure and creativity. The above table shows that students have improved their aspects with the help of formative assessment. There is a large degree of increasing from adequate to very good. Question 13 is meant to summarize what they have learned through the whole semester according to their own opinions. About 80 percent of the students stated that they benefited a lot from the course. It is an open question. From the different results of this question, we concluded that they all held positive attitudes towards English writing and they had more confidence in writing. Their writing ability had been improved in general.

From my observation of the whole semester, we found that students in the experimental class became more active in writing class than the days without formative assessment. During teamwork discussion, they expressed their own ideas in a high mood and some with novel ideas. The attitudes towards English writing were changing from adequate to positive. The ability to use proper words and expressions was also improved. Team spirit and writing ability were increased to a large extent. On the contrary, there was no obvious change of the students in the control class. They showed indifference in teamwork discussion sometimes. The performance in the control class was less cheering, unlike the excitement in the experimental class.

\section{The results of Tests}

The comparative results of the pre-test and the post-test of the two classes are shown in the following table.

\begin{tabular}{|l|l|l|l|}
\hline & $\begin{array}{l}\text { Mean scores } \\
\text { (Full scores } 15 \\
\text { points) }\end{array}$ & $\begin{array}{l}\text { Percentage of } \\
\text { excellent }\end{array}$ & Percentage of pass \\
\hline Experimental class & $11.7 \rightarrow 13$ & $32 \% \rightarrow 48 \%$ & $80 \% \rightarrow 92 \%$ \\
\hline Control class & $11.9 \rightarrow 12.5$ & $36 \% \rightarrow 44 \%$ & $84 \% \rightarrow 88 \%$ \\
\hline
\end{tabular}

I presented the results of the pre-test and the post-test in the above table. The pre-test paper was designed to be at the same difficulty level with the post-test and both of the two tests are argumentative writing. The figures before the arrow are the results of the pre-test. So the figures after the arrow are obtained from the post-test. At the beginning of the course, students of both classes were nearly at the same level, and mean scores of experiment class are 0.2 marks' lower than the control class. Two means in the post-test are higher than those in the pre-test, with the means in the experimental class increasing by 1.3 and the control class increasing by 0.6 . At the end of the course, the final achievement of the experimental class is 0.5 marks higher than that of the control class. Even the percentage of excellent and pass rate of the control group is higher than that of the experimental class before the experiment. However after adopting formative assessment in the experimental class, we noticed a significant difference in this aspect between these two classes. It is clear that the experimental class made greater improvement. Also, the percentage of excellent and pass rate of the experimental class rises in a larger degree than the control class despite the primary opposite proportion. Formative assessment played a key role in the change. All in all, the increase of mean scores or percentage of pass in the experimental class is higher than that in the control class. It follows that even if both of the two classes have improved significantly in their writing ability, formative assessment has enabled quicker improvement, with larger space.

\section{B. Discussion}

\section{Formative Assessment Facilitating English Writing Ability}

The results of the observation, questionnaires, self-assessment and peer-assessment in the formative assessment experiment all show that the application of formative assessment in the English writing class facilitates students' ability to develop thesis, organize paragraphs, choose appropriate vocabulary and manipulate sentences. Self-assessment is essential to students' improvement of writing ability. Students were asked to give their comments and assessment on their own writing after they finished each draft. By means of self-assessment, students continuously reflected on their problems, solutions and progress, and they developed their competence in critical thinking as well. On the other hand, through this activity, the teacher got more information about students' writing purpose, process, doubt, strength and weakness, which helped the teacher to offer an informed and quality feedback to student's writing. Through peer-assessment, students learned to evaluate other students' performance, made reflection on their own writings and revised their own writing wisely. The activity of evaluating others' works helps to strengthen students to voice their views and improve their feelings of being the center of learning. Therefore, students are highly motivated and willing to give or accept suggestions. Students' interests are improved as a result of experience of success and teacher's encouragement and praise. They are motivated to do the library research and verbal report, communicate with others and to revise their writing in order to accomplish their writings. 


\section{Formative Assessment Serving as an Alternative to Summative Assessment}

Educators have realized much negative influence brought by using summative assessment now. From the perspective of students, as a result of overemphasis on the grading of assessment, a small percentage of students who get high marks can be motivated to learn. From the aspect of teacher, the traditional summative assessment is not telling teachers all they need to know about student's progress in writing; these observations or interviews provide teachers with direct evidence of how students engage in English writing process. Since language learning is an ongoing process, there are many decisions to be made during this process. Formative assessment is an ongoing process of gathering information on the extent of learning, on strength and weakness, which the teachers can get feedback into their course planning and the actual feedback they can give to their learners. It occurs during a writing process rather than at the end to provide ongoing feedback to the students so they can improve their work timely. The purpose of formative assessment in writing class is to provide corrective actions, as instruction occurs to enhance student writing ability. It provides significant information to learners about how they are progressing in terms of both their communicative and process skills, helping them to take charge of their own writing methods. Formative assessment also gives teachers valuable information about the process of individual learner's communicative proficiency, personal development, writing skills and social skills. Compared with summative assessment which is unilateral, formative assessment has gained more welcome.

\section{Suggestions on Effective Application of Formative Assessment in College English Writing Class}

Based on the analytic results of the study, some suggestions on how to apply formative assessment effectively in college English writing class are put forward as follows:

(1) Teachers should display their dominant function in formative assessment and show their studying and assessing methods in English writing class. Teachers should organize and guide students to collect and edit assessment, at the same time help them learn self-assessment and peer-assessment. As a result, good writing habit can be formed.

(2) With the existence of consciousness and dependence, activeness and positiveness, the supervision of teachers is necessary. Teachers should check up the portfolio periodically or occasionally to stimulate them to record the portfolio in a logical way. Self-assessment and active learning ability can be formed while cultivating self-constraining ability. Therefore, they can form a good habit in writing.

(3) In the course of formative assessment in writing class, teachers should build their own portfolio in writing teaching. Simultaneously, they should reflect, summarize and record instantly from the aspects of attitude, instructional steps plus instruments and personal achievement. In the instructional process, teachers should emphasize their own assessment, and gain more information through the communication or idea-exchange with other teachers. Consequently, they can improve their English writing teaching methods and enhance their own writing ability.

\section{CONCLUSION}

The experiment conducted shows that formative assessment does have important influence on students' English writing achievement. Formative assessment is an integral part of classroom teaching and learning. It is particularly important to recognize that formative assessment is concerned with keeping track of the learners' progress as it happens and identifies ways of helping it along. Its focus is on the process of learning. It is process assessment that exercises a powerful effect on affective language learning outcomes by enhancing the learners' competence and confidence as an individual. Formative assessment is particularly beneficial to teachers and students. Observation, portfolios, questionnaires and tests are effective methods to prove that formative assessment is helpful to improve students' English writing, to cultivate their team spirit, to stimulate their learning interest and to assist their daily use of English. With summative assessment, on the other hand, the focus of attention is on the result of learning, it is more concerned with identifying overall levels of achievement and measuring what learners do against them. In advocating that formative assessment which serves as an alternative to conventional assessment in English writing class, the author of the present paper does not deny the proper use of language summative assessment. What is important is that in the process of language teaching and learning, both two types of assessment should be adopted appropriately, with an emphasis on the use of formative assessment, and much work has to be done for the further study of formative assessment. Although I tried my best to do the experiment, it was only done in a small field. It is a small part under the big task. To enable students to fully benefit from it, I hope there will be more and more researchers who are ready to devote to this ongoing research topic of language teaching and learning.

\section{APPENDIX I. QUESTIONNAIRE I}

请你根据平时英语写作中的表现回答以下问题。在以下各个问题后面，附有种不同的选择。由于个人情况不 同，任何选择都是可能的，不存在答案正确或者错误的问题。

1.英语写作 - . .

$\mathrm{A}$ 很有趣 $\mathrm{B}$ 有趣 $\mathrm{C}$ 一般 $\mathrm{D}$ 没意思

2. 平时你 _ - 地完成写作任务

$\mathrm{A}$ 很积极 $\mathrm{B}$ 积极 $\mathrm{C}$ 一般 $\mathrm{D}$ 拖沓

3. 你对英语写作 - . . 
A 很自信 B 自信 C 一般 D 害怕

4. 你认为老师的评语 - - .

$\mathrm{A}$ 很重要 B 重要 C一般 D 不重要

5. 你认为反思对写作能力的提高 - - .

$\mathrm{A}$ 很重要 $\mathrm{B}$ 重要 $\mathrm{C}$ 一般 $\mathrm{D}$ 不重要

6. 你认为和同伴讨论你们的论文 - - .

$\mathrm{A}$ 很有必要 $\mathrm{B}$ 有必要 $\mathrm{C}$ 有时有必要 $\mathrm{D}$ 没必要

7. 写作时我 - - 打草稿并再三思考修改.

$\mathrm{A}$ 总是 $\mathrm{B}$ 经常 $\mathrm{C}$ 有时 $\mathrm{D}$ 很少

8. 你的作文在观点明确、有情感、有意义方面表现 - .

$\mathrm{A}$ 优秀 $\mathrm{B}$ 良好 $\mathrm{C}$ 合格 $\mathrm{D}$ 需再努力

9.你的作文在表达清楚、逻辑性强方面表现 - . .

$\mathrm{A}$ 优秀 $\mathrm{B}$ 良好 $\mathrm{C}$ 合格 $\mathrm{D}$ 需再努力

10.你的作文在用词准确性及多样性方面表现 - - .

$\mathrm{A}$ 优秀 $\mathrm{B}$ 良好 $\mathrm{C}$ 合格 $\mathrm{D}$ 需再努力

11. 你的作文在主谓搭配、时态运用、主谓一致、句式变化等方面表现 - - .

A 优秀 $\mathrm{B}$ 良好 $\mathrm{C}$ 合格 $\mathrm{D}$ 需再努力

12.你的作文拼写与标点 - - .

$\mathrm{A}$ 完全正确 $\mathrm{B}$ 基本正确 $\mathrm{C}$ 偶尔有创造力 $\mathrm{D}$ 缺乏创造力

\section{APPENDIX II. QUESTIONNAIRE I FOR ENGLISH WRITING}

请你根据平时英语写作中的表现回答以下问题。在以下各个问题后面, 附有种不同的选择。由于个人情况不 同，任何选择都是可能的，不存在答案正确或者错误的问题。

Questions 1-12 are the same as those in questionnaire I

13. 谈谈你这一学期以来对英语写作的体会。

\section{APPENDIX III. PRE-TEST PAPER FOR WRITING PROFICIENCY}

Class___ Name_____ Student Number____ Grade

It reported that some sophomore in a university decided to try their hands at business in order to get prepared for future. They opened five shops near the university. Their teachers and students had different opinions about this phenomenon. Some thought that their business experience would help them adapt better to the society after graduation, while other held a negative view, saying that running shops would occupy much time of students' time and energy which should be devoted to their academic study. What do you think? Write a composition of 200-250 words on the following topic:

Should University Students Go in for Business?

In the first part of your writing you should state clearly of your main argument, and in the second part you should support your argument with appropriate details. In the last part you should bring what you have written to a natural conclusion or a summary.

Marks will be awarded for content, organization, grammar and appropriateness. Failure to follow the above instructions may result in a loss of marks.

\section{APPENDIX IV. POST-TEST FOR WRITING PROFICIENCY}

Class___ Name____ Student Number____ Grade

In our culture, many regard "You are very smart" the most pleasant compliment. Parents like to hear that their children are clever; students like to hear that they are quick-minded; seniors are pleased with the comment that they are wise persons. These phenomena raise a question -- Is intelligence really that important? Yet, some successful people do not agree. They believe "diligence" is more important than intelligence.

Topic: Intelligence or Diligence

What's your view on this issue? Write an essay of about 300 words with evidence.

Your argument will be evaluated according to the criteria listed above.

\section{REFERENCES}

[1] Andrew, D. C. (2005). Assessing Language Ability in the Classroom. Beijing: Foreign Language Teaching and Research Press.

[2] Bachman, L. F., A. S. Palmer. (1996). Language Testing in Practice. Oxford: Oxford University Press.

[3] Black, D. (2002). et al, New Directions in Portfolio Assessment, Portsmouth, NH: Boynton/Cook.

[4] Black, P., D. William. (1998). Assessment and Classroom Learning. Assessment in Education. 
[5] Black, P., C. Harrison. (2001). Self-assessment and Taking Responsibility: The Science Students' Role in Formative Assessment. The School Science Review.

[6] Black, P., D. William. (1998). Assessment and Classroom Learning: Assessment in Education. Academic Research Library.

[7] Black, P., D. William. (1998). Inside the Box: Raising Standards through Classroom Assessment. Phi Delta Kappan.

[8] Black, P. (2003). et al. Assessment for Learning: Putting it into Practice. Buckingham: Open University Press.

[9] Bloom, B.S. (1981). Taxonomy of Education Objective. New York: Mc Graw-Hill.

[10] Bloom, B.S. (1971). Handbook of Formative and Summative Assessment on the Study of Students, New York: Mc Graw-Hill.

[11] Bloom, B.S. (1986). Education Assessment. New York: Mc Graw-Hill.

[12] Carol, A. D. (1998). Assessment and Classroom Learning: Theory and Practice. Assessment in Education. Academic Research Library.

[13] Cowie and Bell. (1996). Formative Assessment and Science Education. Kluwer Academic Publishers, Norwell, MA, United States.

[14] Scriven. (1967). M. The Methodology of Evaluation. Washington, D. C.: American Educational Research.

[15] Tayler, L., D. William. (1942). Evaluation and Record of Advancement of Student Chicago: The University of Chicago Press.

Yang Liu was born in Jilin, China in 1978. She received her master degree in linguistics from Changchun University of Science and Technology, China in 2007.

She is currently a lectorate in the School of Foreign Languages, Changchun University of Science and Technology; Changchun, China. Her research interests include psycholinguistics and inter-cultural communication. 